\author{
Ilkhom A. Begmatov ${ }^{1}$, Bakhtiyar Sh. Matyakubov ${ }^{2}$, Doniyor E. Akhmatov', \\ Mukhayo V. Pulatova ${ }^{4}$
}

\title{
ANALYSIS OF SALINE LAND AND DETERMINATION \\ OF THE LEVEL OF SALINITY OF IRRIGATED LANDS \\ WITH USE OF THE GEOGRAPHIC INFORMATION SYSTEM TECHNOLOGIES
}

\begin{abstract}
In Uzbekistan, more than half of population lives in rural area, their well-being depends on quality of land and water resources availability. Quality of land is determined by ameliorative indicators: ground water depth level, ground water salt amount and salinity of soil. These factors do not appear naturally but rather due to the human activity. Inefficient irrigation and excessive consumption of irrigation water on irrigated land in Boyavut District of Syrdarya region of Uzbekistan within several decades have led to a salinization of soil. The primary objective of this article is determination of the level of salinity of soil for modelling spatial distribution of soil salinity throughout an irrigated land by using GIS technology. This technology is focused on automation of development and creation of ameliorative maps, while totally eliminating manual operations. Nowadays, ameliorative expedition specialists still create cadastral map using tracing paper over the marginal areas within irrigated lands based on their ameliorative conditions and by selecting from the three thematic maps and then selecting the poorest conditions of ameliorative indicators. The suggested technology is designed for professionals of cadastral subdivisions of regional ameliorative expeditions, who use the GIS-based software, such as ArcView 3.2. or ArcGIS 10x; their duties include creating of thematic maps based on salinity levels of irrigated lands. Exact coordinates of collection sites of soils samples (collected in 2018-2019) were determined using GPS. The Inverse Distance Weighting (IDW) interpolation method was applied to use that data to create ameliorative maps categorized by the salinity levels (non-saline, slightly saline, saline area and highly saline areas). Those maps were then analysed to develop procedures on how to improve ameliorative conditions of irrigated areas.
\end{abstract}

KEY WORDS: Syrdarya region, soil degradation, the degree of salinization of soils, land reclamation cadaster, GIS

\section{INTRODUCTION}

Uzbekistan is currently developing in all areas of rapid growth, which has not been neglected in the field of water reclamation. First of all, let's talk about the relevance of this article. Prior to the introduction of GIS technologies in the field of reclamation, land reclamation map was a problem for staff, for example, one district needs 10-12 working days to produce a single soil salinity map, whereas there are more than 10 districts in the region. This means that a lot of time and staff salaries required a substantial budget.

We are currently on a high-performance, low-cost labor force using GIS technology, which is the application of GIS technology to analyze and evaluate soil salinity [Abdelfattah et al., 2009].

\footnotetext{
${ }^{1}$ Tashkent Institute of Irrigation and Agricultural Mechanization Engineers (TIIAME), Kori Niyaziy str., 39, 100000, Tashkent, Uzbekistan; e-mail: ilkhommatbe@mail.ru

${ }^{2}$ Tashkent Institute of Irrigation and Agricultural Mechanization Engineers (TIIAME), Kori Niyaziy str., 39, 100000, Tashkent, Uzbekistan; e-mail: bmatyakubov@inbox.ru

${ }^{3}$ Department of Ameliorative Expedition of Adminstration of Low Syrdaya Basin Irrigation System, A.Timur str.,

53, Gulistan, Syrdarya, Uzbekistan; e-mail: doniyor19940802@gmail.com

${ }^{4}$ Tashkent Institute of Irrigation and Agricultural Mechanization Engineers (TIIAME), Kori Niyaziy str., 39 , 100000, Tashkent, Uzbekistan; e-mail: mukhayo94@mail.ru
} 
Geographic information system (GIS) "Amelioration" of the region is based [Abdul-Qadir et al., 2010] on thematic ameliorative spatial data, which are used in the form of the distributed data bases at construction of true-to-life <maps> <reflecting > current ameliorative situation of irrigated lands in the region, and are used in cartographic materials and ameliorative cadastre.

In the absence of a corresponding set of ameliorative indicators (ground water level (GWL), ground water salt content (GWSC), the data on extension of the level of salinization of soil with monitoring of distribution of salts in the soil layer in the thickness of one metre, salts carry-over by collector-and-drainage network) and ensuring continuous updating of the specified spatial data, the GIS "Amelioration" cannot provide the ameliorative cadastre with the visualised objective data ${ }^{1}$. Which materials are used for development of the measures focused on improvement of the ameliorative condition of the land, and, as a result, aimed at enhancement of yield of the basic crops ${ }^{2}$.

The use in productive activity of the ameliorative expedition is aimed at maintenance of uniformity of the field data acquisition technology for future use in the database of the GIS "Amelioration" and updating with chronological and current data of the ameliorative cadastre ${ }^{3}$.

The information, collected in field conditions, will be substantially interesting for assessment through a spatial situation analysis of movement of subsoil water, accumulation of salts at separate irrigated land areas and determination of associated conditions [Rahimov, Saidov, 2019].

The salinization of water management soil and the practical use of water in furrow irrigation were studied, as well as the transpiration of water from a field site ${ }^{4}$ [Kenjabaev et al., 2020].

\section{MATERIALS AND METHODS OF RESEARCHES}

Based on the normative instruction No 132 dated June 26, 2007, approved by the Ministry of Agriculture and Water Management, it is indicated that the establishment of sowing plots available in our Republic and the level of development of crops is carried out in August. Primary field observations are conducted in the context of water consumers.

Field observations are carried out by agronomists, soil experts and land reclamation technicians, together with the heads of Water Consumer Associations and heads of farms.

Points of soil collection are determined by the contour of areas where the crop development is good, medium or fair.

At the same time, according to the level of development of crops, a relative level of soil salinity is established. In particular:

- plots with good crop development belong to the class of least saline plots;

- plots with medium crop development — to the class of plots of medium salinity;

- plots with poor crop development - to the class of the most saline plots, which are marked in the working map with a scale of 1: 10000 and are recorded in the journal.

Soil samples with slightly saline level are determined using 10 points for every 100 ha of land, while soil samples with medium and high salinity levels at 16 points for every 100 ha of land, namely:

\footnotetext{
${ }^{1}$ Begmatov I.A. Land meliorative status in irrigated lands of Syrdarya province. Journal of European Science Review. Austria, Vienna, 2017. P. 177-181

${ }^{2}$ Ikramov R.K., Begmatov I.A. Up-to-date melioration state of irrigation area of the Hungry Steppe (uzber part) and ways of sustainable increasing their productivity. Irrigation and melioration. Tashkent, 2015. No 2. P. 14-17

${ }^{3}$ Ikramov R.K., Schzdyukova L.Kh., Saidov A.A., Begmatov I.A. The present meliorative statatus and meliorative regime of irrigated lands of Syrdarya region. Materials of the Republican scientific and practical conference. Issues of improving the effective use of water resources and improving land reclamation and environmental ecology. Tashkent, 2012 (in Russian)

${ }^{4}$ Mohan R., Jumaboev K., Matyakubov B., Eshmuratov D. Evaluation of furrow irrigation practices in Fergana Valley of Uzbekistan. Agricultural water management, 2013. P. 133-144
} 
- $\quad$ in non-saline areas (according to the salinity established for the previous year), up to 15-25 hectares can be established depending on the hectares along the contour;

- $\quad$ in slightly saline areas (with good crop development) - up to 10-12 ha, depending on the hectares along the contour;

- $\quad$ in areas of moderate salinity (with medium crop development) - up to 7-8 ha, depending on the hectares along the contour;

- $\quad$ in areas of severe salinity (with poor development of crops) - it is necessary to establish up to 5-7 ha depending on the hectares along the contour, since with a small area attached at the point of soil intake, the accuracy of the data obtained will be the highest [Rahimov, Saidov, 2019].

On the working map, sampling points for soil samples are determined and, after drawing the point limits, farm boundaries, observation wells, canals and reservoirs, slightly saline areas turn yellow, areas of medium salinity turn brown, and underdeveloped areas turn red depending on what was discovered during studying in each field with field visits such characteristics of crops as color, growth, plant density, color of the upper soil layer.

Corresponding notes are entered in the observation journal if, for example, the development of a cotton crop in normally saline areas amounts to $12-15$ boxes, in medium-saline areas 10-12, and in underdeveloped areas the number of boxes is 8-10 [Yulbarsov, 2019]. After studying the map and data by the engineer and agronomic soil scientists of the department, the identified deficiencies are eliminated and a permit for soil collection is issued.

\section{RESULTS OF RESEARCHES AND THEIR DISCUSSION}

Golodnaya steppe is a vast intermountain plain, completely deserted in the past, located on the left bank of Syrdarya River in mid-channel thereof. The Uzbekistan part of Golodnaya steppe is a part of the Syrdarya region and includes 8 administrative districts (fig. 1).

Total area $-427,618$ thousand ha, including those irrigated -287 thousand ha. Climate is sharp continental, average long-term amount of precipitations of 260-312 mm. Northern part of the plain, from a surface to $15-40 \mathrm{~m}$, is represented by loessial loams with underlaying gravelsandy deposits; Southern part is represented by deluvial and proluvial, and by peripheral deposits of alluvial cones of ephemeral flows from the Turkestani ridge hillside.

The soils in composition are more than on $60 \%$ light and middle loamy, and on $28 \%$ are heavy loamy and clayey. Under current conditions, 222 thousand ha of irrigated land are exposed to salinization at varying level, including 117 thousand ha are medium and and highly saline. The area of the land, where the ground water depth level is up to $2 \mathrm{~m}$, is 83 thousand ha, and with the salt content of more than $3 \mathrm{~g} / \mathrm{l}-204$ thousand ha.

The basic natural factors of formation of hydrogeologic and ameliorative conditions of Golodnaya steppe are: land forms, lithologic structure of the rocks of the aeration zone, waterbearing horizons and chemical composition of subsurface water. All three factors determine the degree of natural drainage conditions of the territory. The nature of anthropogenous impact (irrigation, hydromeliorative systems, construction of water-storage basin) influences dynamics and trend of development of exogenous geological processes (raised water table and salinization of rocks of the aeration zone), which is responsible for ameliorative condition of land.

First of all, we install the ArcGIS program on the computer and determine the boundaries of the required area.

We carry out sampling of soil samples and using GPS indicate the dynamic point of soil intake on the map (fig. 2 and 3).

After that, we summarize the boundaries of a specific plot, dynamic points designed using GPS, data received from the laboratory using these points (fig. 4). 


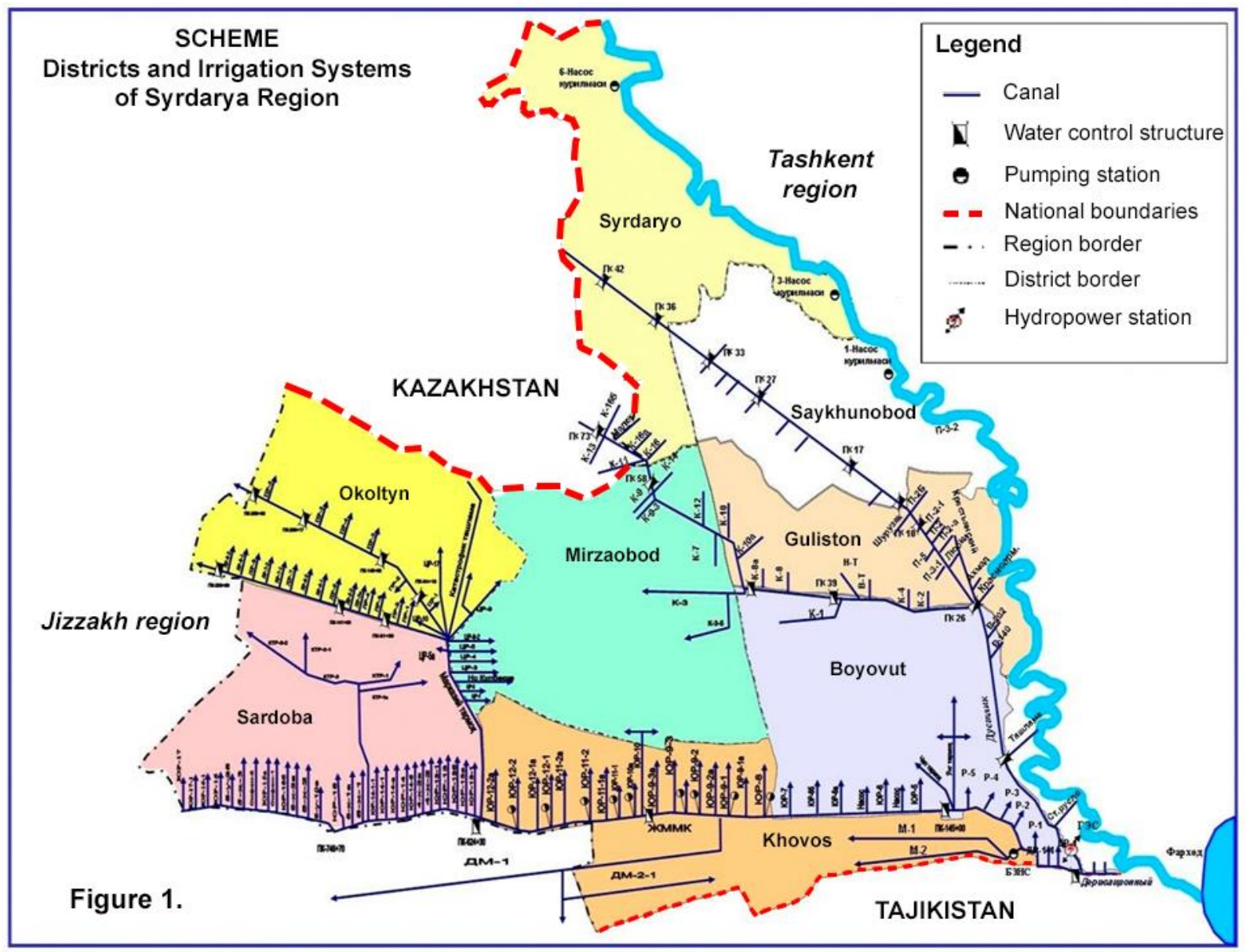

Fig. 1. The map of the districts of the Syrdarya region with the irrigating system
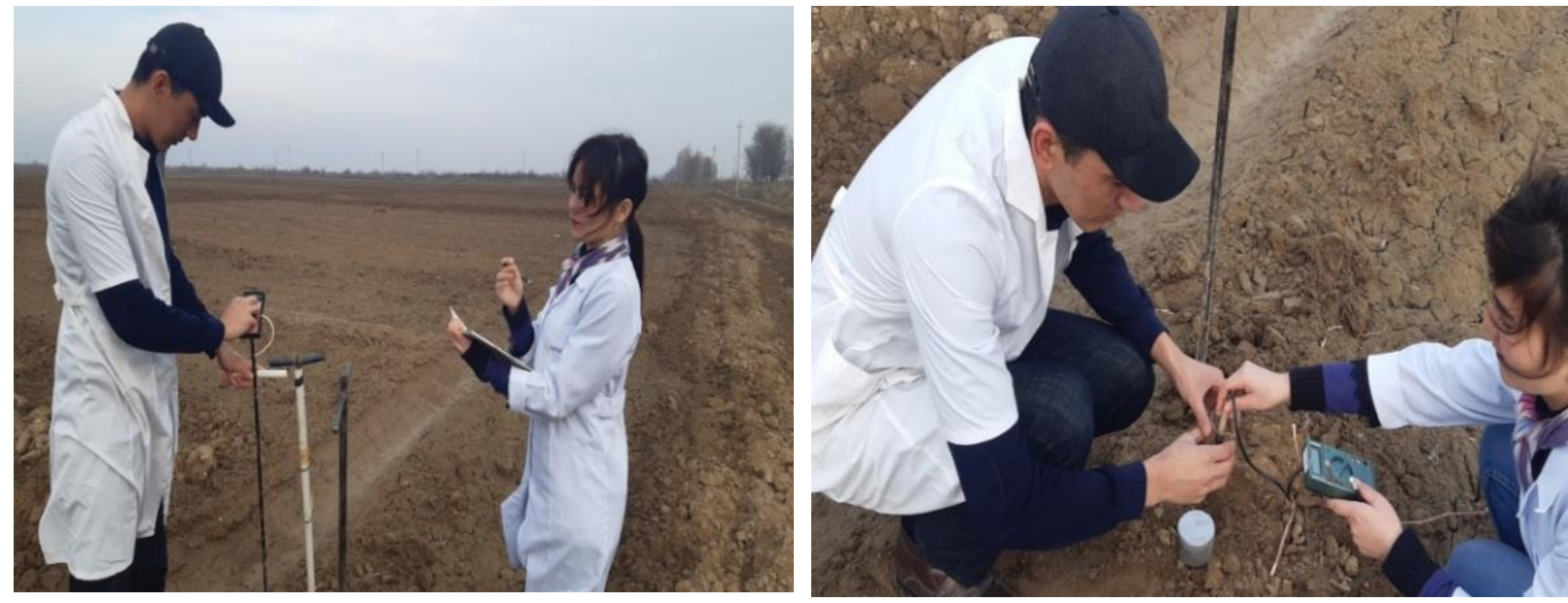

Fig. 2. Process of obtaining in suite data 



Fig. 3. Determine the content of chloride in the selected soil samples in laboratory

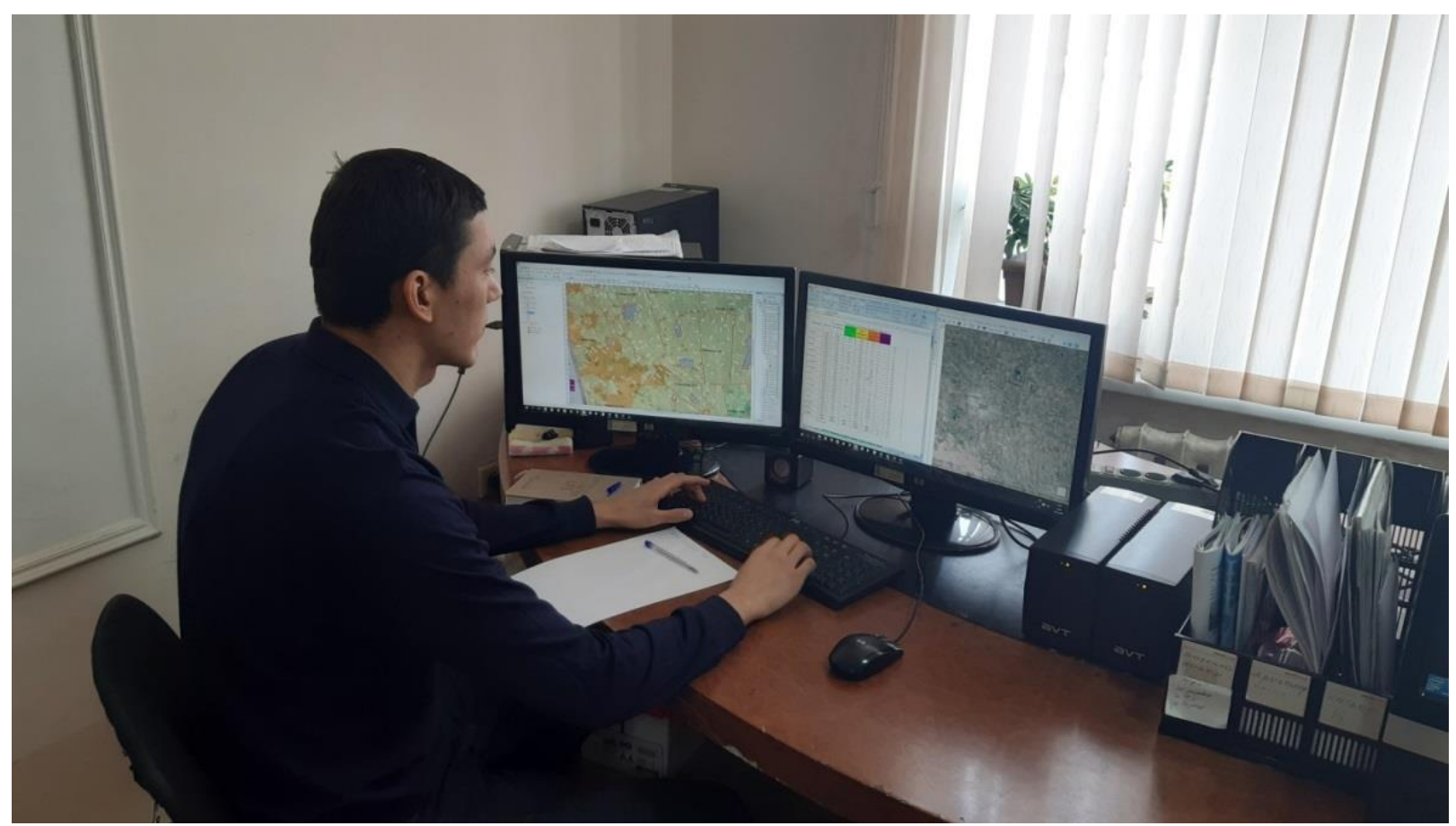

Fig. 4. Entering the obtained data into the GIS database

Open the ArcMap application and go to the Spatial Analyst toolbar in the ArcToolbox window (fig. 5). We derive the data analysis within the required plot using the IDW Interpolation algorithm method and at the next stage we divide the data obtained by classes:

Non-saline $0-0.01$, lightly saline $0.01-0.03$, average salinity $0.03-0.07$, highly saline 0.07 $<.$. etc. [Tursunov, 1981].

From the existing reclamation map, we determine the tables, that is, the state of the hectares, for this we use the formula:

$$
\text { [COUNT] / } 100 * \text { LUC. }
$$

Where, COUNT is number of pixels $\left(10^{*} 10 \mathrm{~m}\right)$ for each category, LUC is land use coefficient and this was calculated as: Agricultural land area of district (Netto area) divided by overall area (Brutto area) of the district. 
Table 1. Information on the degree of salinization of land in the farms of the Boevut district as of October 1, 2018-2019

\begin{tabular}{|c|c|c|c|c|c|}
\hline \multirow[b]{2}{*}{ Farms } & \multirow[b]{2}{*}{ Years } & \multirow[b]{2}{*}{$\begin{array}{c}\text { Irrigated } \\
\text { area, ha }\end{array}$} & \multicolumn{3}{|c|}{ Degree of salinization of land by chlorine, $\%$} \\
\hline & & & $\begin{array}{c}\text { Non-saline area, } \\
\text { ha }\end{array}$ & $\begin{array}{l}\text { Slightly saline } \\
\text { area, ha }\end{array}$ & Saline area, ha \\
\hline \multirow{2}{*}{ Latipov } & 2018 & 1320 & 40 & 1169 & 111 \\
\hline & 2019 & 1320 & 30 & 1279 & 11 \\
\hline \multirow{2}{*}{ Navoiy } & 2018 & 1177 & & 1173 & 4 \\
\hline & 2019 & 1177 & 9 & 1159 & 9 \\
\hline \multirow{2}{*}{ Navruz } & 2018 & 1274 & & 1272 & 2 \\
\hline & 2019 & 1274 & 627 & 647 & \\
\hline \multirow{2}{*}{ Tarraqiyot } & 2018 & 1983 & 30 & 1853 & 100 \\
\hline & 2019 & 1983 & 12 & 1834 & 137 \\
\hline \multirow{2}{*}{ Maxmudov } & 2018 & 1046 & 9 & 1034 & 3 \\
\hline & 2019 & 1046 & & 808 & 238 \\
\hline \multirow{2}{*}{ Dehqonobod } & 2018 & 2418 & 130 & 2138 & 150 \\
\hline & 2019 & 2418 & & 1950 & 468 \\
\hline \multirow{2}{*}{ Sh. Rashidov } & 2018 & 1096 & & 764 & 332 \\
\hline & 2019 & 1096 & & 864 & 232 \\
\hline \multirow{2}{*}{ Boyovut-1 } & 2018 & 6208 & 83 & 6121 & 4 \\
\hline & 2019 & 6208 & 4 & 6204 & \\
\hline \multirow{2}{*}{ Gallakor } & 2018 & 2749 & & 2749 & \\
\hline & 2019 & 2749 & & 2739 & 10 \\
\hline \multirow{2}{*}{ U. Yusupov } & 2018 & 4259 & & 4250 & 9 \\
\hline & 2019 & 4259 & & 4044 & 215 \\
\hline \multirow{2}{*}{ Boyovut-3 } & 2018 & 5871 & 8 & 5853 & 10 \\
\hline & 2019 & 5871 & & 5634 & 237 \\
\hline \multirow{2}{*}{ Galaba } & 2018 & 3414 & & 1174 & 2240 \\
\hline & 2019 & 3414 & 16 & 1730 & 1668 \\
\hline \multirow{2}{*}{ Navbaxor } & 2018 & 2697 & & 1665 & 1032 \\
\hline & 2019 & 2681 & & 1907 & 774 \\
\hline \multirow{2}{*}{ Shirin } & 2018 & 785 & & 777 & 8 \\
\hline & 2019 & 785 & & 781 & 4 \\
\hline \multirow{2}{*}{ Total } & 2018 & 36297 & 300 & 31992 & 4005 \\
\hline & 2019 & 36281 & 698 & 31580 & 4003 \\
\hline
\end{tabular}

\section{Primary reasons of the stated ameliorative condition}

The average salt content in irrigating water has changed by months from $0.9 \mathrm{~g} / \mathrm{l}$ to $1.6 \mathrm{~g} / \mathrm{l}$ within last three years.

Taking into account that irrigating water salt content has increased in 2-3 times (the standard salt content in irrigating water is $0.5 \mathrm{~g} / \mathrm{l}$ ), then the situation is worsening more.

Based on the data of the Department of Ameliorative Expedition of Adminstration of Low Syrdaya Irrigation System, water availability for fields irrigation is 0.95 within a vegetative period. Within non-vegetation period, despite satisfactory water supply of Syrdarya region, water 
availability is 0.4 . The reason is breach of operating procedures of washing, organisational shortcomings. Actually, water supply in the district is insufficient.

The factor of washing regime of irrigated fields was $C_{w}=0.87$ that is insufficient for soil desalination (according to recommendations of the Central Asian Scientific Research Irrigation Institute (CASRII) it should be $\mathrm{C}_{\mathrm{w}}=1.2-1.3$ ) [Ikramov, 2001].

According to the Department of Ameliorative Expedition of Adminstration of Low Syrdaya Irrigation System, capacity of interfarm and intrafarm canals has been reduced in past years.

Taking into account the above-stated data, the conclusion can be made that the groundwater table is raised every year. The reason is insufficient capacity of drainage systems.

The vertical wells water discharge is reduced in 3-4 times.



Fig. 5. Map of soil salinization of irrigated lands of the Boevut District of the Syrdarya region as of 01.10.2019

In 2018-2019, the groundwater table recedes on the irrigated lands of Boyavut district, but it did not exceed the threshold level recommended by the CASRII on more than 2-3 $\mathrm{m}$ within a vegetation period. There is a tendency of ground water salt content reduction: on the area of $>60$ $\%$ - ground water salt content is above $3 \mathrm{~g} / \mathrm{l}$ that is assessed as the unsatisfactory condition.

According to Department of Ameliorative Expedition, more than $90 \%$ of land are slightly saline, however according to a soil survey, performed by the Committee of UzGeodezCadastre, the area of non-saline and slightly saline land is 51.46-71.25\%, remained (26.92-28.75\%) land is assessed as medium, highly and very highly saline. And this is more than the Department of Ameliorative Expeditions data on $10 \%$ on average. 
According to Department of Ameliorative Expedition, there is a tendency of soil salinity to decrease. Yield of cotton and wheat in district is low and medium (cotton - 23.8-27.9 centner/ha, wheat - 49.7-53.7 centner/ha).

\section{CONCLUSIONS}

Keeping inventory of soil samples collected on irrigated lands in Boyavut district is important as the data clearly shows salinity levels distribution across the area. Additionally, such a database allows exhibiting tendency of decline of ground water table levels and decreasing in ground water mineralization levels. For example, in 2018, slightly salinized soil was at 31992 ha $(88.14 \%)$, while in 2019, same soil was at 31580 ha (87.04 \%). Similarly comparing soils with zero salinity levels, the area increased from 300 ha (0.83\%) in 2018 to 698 ha (1.92\%) in 2019. The latter has resulted in a higher yield harvest of all grown crops across the area.

The application of GIS and other advanced computer technologies will help to fairly and quickly identify lands that are subject to reclamation improvement, while complex reconstruction of irrigated lands allows for cost-performance. Specialists who are trained to apply GIS technology will be able to determine specific irrigated areas and fields that need to be effectively improved and subsequently maintained at their reclamation state. Widespread application GIS and remote sensing technologies for proper irrigation management as well as analysis of the condition of collector and drainage networks represents opportunities for monitoring ameliorative condition of agricultural lands.

\section{ACKNOWLEDGEMENTS}

The conducted research was funded by the Ministry of Water Resources of the Republic of Uzbekistan. The authors express their deep gratitude for the assistance in conducting research to the reclamation expedition staff of the Administration of Lower Syrdarya Basin Irrigation Systems.

\section{REFERENCES}

1. Abdelfattah M.A., Shahid S.A., Othman Y.R. Soil salinity mapping model developed using RS and GIS: A case study from Abu Dhabi, United Arab Emirates. Eur. J. Sci. Res., 2009. V. 26. P. 342-351.

2. Abdul-Qadir A.M., Benni T.J. Monitoring and evaluation of soil salinity term of spectral response using Landsat images and GIS in Mesopotamian plain Iraq. J. Desert Stud., 2010. No 2. P. 19-32.

3. Ikramov R.K. Principles of water-salt regime management of irrigated lands of Central Asia in conditions of water resources deficit. Tashkent: Hydroingeo, 2001. 192 p. (in Russian).

4. Kenjabaev Sh., Frede H.G., Begmatov I., Isaev S., Matyakubov B. Determination of actual crop evapotranspiration (etc.) and dual crop coefficients (kc) for cotton, wheat and maize in Fergana Valley: Integration of the FAO-56 approach and budget. Journal of Critical Reviews, 2020. V. 7. Iss. 5. P. 340-349.

5. Rahimov N., Saidov R. Assessment melioration condition of irrigated lands and its improvement. Info capital group. Tashkent, 2019. 95 p. (in Russian).

6. Tursunov M. Guidelines for salt testing of irrigated lands and determination of wash irrigation standards. Tashkent, 1981 (in Russian).

7. Yulbarsov B. Technical report of the Melioration expedition of Lower-Syrdarya irrigation systems Basin Department of Syrdarya for 2019. Syrdarya, 2019 (in Russian). 